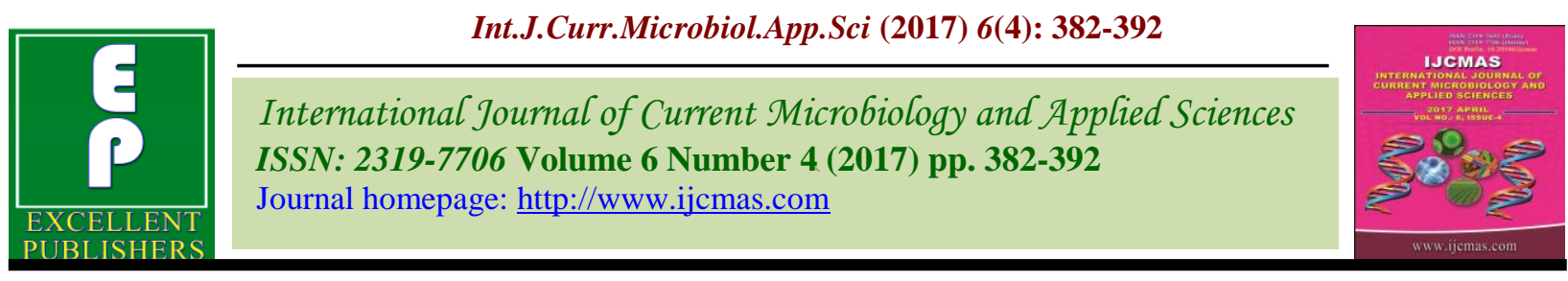

Review Article

https://doi.org/10.20546/ijcmas.2017.604.043

\title{
Quantifying the Stock of Soil Carbon Sequestration in Different Land Uses: An Overview
}

\author{
Mehraj Ud Din Khanday ${ }^{1}$, J.A. Wani, D. Ram ${ }^{1}$ and Rukhsana Jan ${ }^{2}$ \\ ${ }^{1}$ Division of Soil Science, SKUAST-K, Srinagar-190025, India \\ ${ }^{2}$ Division of Agronomy, SKUAST-K, Srinagar-190025, India \\ *Corresponding author
}

\begin{abstract}
A B S T R A C T
International efforts to mitigate human-caused changes in the Earth's climate are

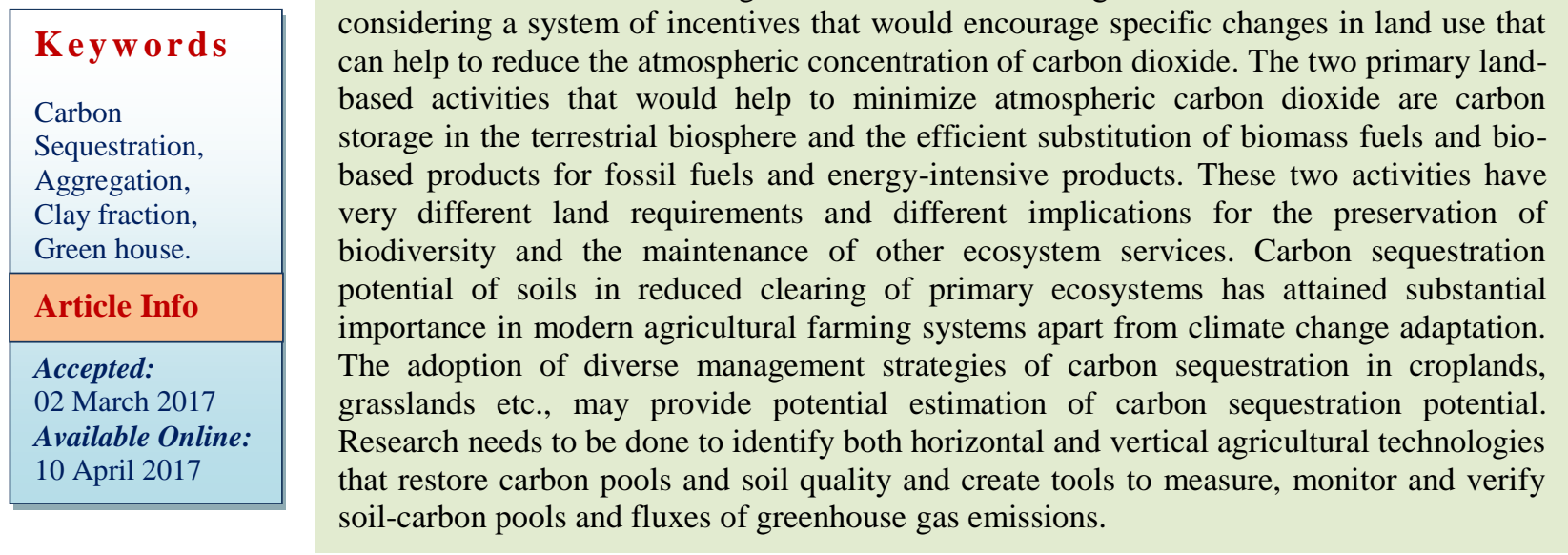

\section{Introduction}

World soils constitute the largest terrestrial carbon (C) pool, estimated at about $4000 \mathrm{Pg}$ $(\mathrm{Pg}=1015 \mathrm{~g}=1$ billion or gigaton $)$ to $3-\mathrm{m}$ depth. The soil $\mathrm{C}$ pool has two components: soil organic $\mathrm{C}$ (SOC) and soil inorganic $\mathrm{C}$ (SIC) pools. The SOC pool is highly reactive and plays an important role in the global $\mathrm{C}$ cycle (GCC). It can be a source or sink of greenhouse gases (GHGs) depending on land use and management. Soils have been source of GHGs ever since the dawn of settled agriculture about 10 to 12 thousand years ago, because of conversion of natural to managed ecosystems through deforestation, biomass

burning, land drainage, mechanical seedbed preparation and nutrient mining through extractive farming practices. Thus, soils of agroecosystems contain lower SOC pool than their counterparts under natural ecosystems. The magnitude of SOC loss in agroecosystems may be $20-40 \mathrm{Mg} \mathrm{C} / \mathrm{ha}$. The loss of SOC is generally more from tropical than temperate ecosystems, coarser than finetextured soils, and those managed by extractive farming than science-based inputs. Accelerated erosion and other degradation processes aggravate the depletion of SOC pool. The projected climate change, 
accelerated erosion, and the attendant increase in soil temperature may exacerbate the rate and magnitude of SOC depletion.

\section{Soil carbon sequestration}

Soil C sequestration implies transfer of atmospheric $\mathrm{CO}_{2}$ into the soil $\mathrm{C}$ pol of long mean residence time either as humus or as secondary carbonates. The rate of $\mathrm{C}$ sequestration ranges from 0 to $1 \mathrm{Mg} / \mathrm{ha} / \mathrm{yr}$ as humus and 2-5 $\mathrm{Kg} / \mathrm{ha} / \mathrm{yr}$ as secondary carbonates (Lal, 2004). The potential of SOC sequestration is limited in soils of the dry tropics (Lam et al., 2013). The strategy of SOC sequestration as humus is to create a positive $\mathrm{C}$ (and $\mathrm{N}, \mathrm{P}, \mathrm{S}$, and $\mathrm{H} 2 \mathrm{O}$ ) budget in soil through conversion to a restorative land use and adoption of recommended management practices (RMPs). Some examples of RMPs include conservation agriculture (CA) with retention of crop residue mulch and incorporation of cover crops in the rotation cycle along with the use of complex cropping systems and integrated nutrient management (e.g., manuring), agroforestry, and other conservation-effective measures. The strategy is to adopt sustainable intensification (SI). The SI implies producing more from less through improvement of soil quality. In practice it means more agronomic production per unit of land area, per drop of water, per unit input of fertilizers and pesticides, per unit of energy, and per unit of $\mathrm{CO}_{2}-\mathrm{C}$ emissions.

\section{Carbon storage and sequestration}

Globally there is a generally positive relationship between biodiversity and carbon stocks (Midgley et al., 2010): tropical moist forests, unaffected by direct anthropogenic disturbances like logging and fire, are rich in both. Within tropical forests there is less correlation between spatial patterns of carbon stocks and biodiversity in undisturbed areas and the patterns are complex (Talbot, 2010). At the macro-level, there is considerable variation from one tropical forest region to another in the number of species supported per unit area, but there is as of yet no compelling evidence that the most diverse tropical forests are also the most carbon-rich. In Amazonia there is little correlation between areas of highest species richness and areas of highest above ground biomass (Talbot, 2010).

A great deal of uncertainty still surrounds biomass distributions and their causes, and different research groups and different approaches (including remote-sensing and ground-based measurements) have found different results.

Overall, few studies yet exist that address whether the variation in biodiversity coincides empirically with large variation in biomass and soil carbon stocks. Whether and to what degree biodiversity influences carbon stocks in tropical forests is still uncertain, although experimental work in other ecosystems has shown that biodiversity often promotes stability and primary productivity, and therefore carbon stocks (Miles et al., 2010a).

\section{Principal mechanisms that determine SOC and SIC sequestration in soils}

These mechanisms are generally addressed as physical and chemical processes. In contrast, this review takes a soil ecological approach to describe the four mechanisms listed below and provides a unifying conceptual framework that combines all mechanisms into a single and provocative model. i) Soil aggregation and carbon sequestration ii) interaction of carbon with clay fractions iii) transport of dissolved organic carbon into subsoil horizons iv) formation of secondary (pedogenic) carbonates. 


\section{Soil aggregation and carbon sequestration}

Soil aggregation implies the formation of secondary particles or aggregates through flocculation of clay colloids and the cementation of floccules by organic and inorganic materials. Gijsman and Thomas (1995) and Gijsman (1996) observed a strong non-linear relationship between aggregate stability and hot-water extractable carbohydrates of microbial or plant-derived origin in a tropical Latin American Oxisol. An increase of microbially-derived carbohydrates in the clay and silt-sized fractions has been observed by Feller et al., (1991) and Guggenberger et al., (1995). Microbial-derived carbohydrates can be separated from those sugars of plant origin.

In the former group, galactose (G) and mannose (M) accumulate preferentially in the fine fractions, whereas plant-derived sugars arabinose $(\mathrm{A})$ and xylose $(\mathrm{X})$ are dominant in coarse fractions. The $\mathrm{G}+\mathrm{M} / \mathrm{A}+\mathrm{X}$ ratio is higher in clay-size separates. On the death of roots and hyphae the stability of macroaggregates declines at about the same rate at which plant material decomposes in soils. The degradation of macro-aggregates creates micro-aggregates that are considerably more stable than macro-aggregates. For aggregates $<20 \mu \mathrm{m} \varnothing$ there appears to be a random mixture of clay microstructures, biopolymers and microorganisms. The general structure of an aggregate is outlined in figure 1 .

\section{Interaction of carbon with clay fractions}

The relationship between clay type and content and SOM accumulation and stabilization is complex. Clay content is usually correlated with factors that result in SOM production, like plant nutrients and water regime, and also to the formation of aggregates. Residence times of SOC in clay minerals can exceed a hundred years (Laird,
2001), compared to several months for partially mineralized SOC. The SOM associated to silt- and clay-size fractions has a strong link to mineral particles, so that an OM-mineral complex is formed. The majority of the research on SOM linkages with particle-size fractions is from 2:1 clay temperate soils. In these studies, $10-30 \%$ of total SOC pool is associated with the sandsize fraction $(>50 \mu \mathrm{m}), 20-40 \%$ with the siltsize fraction $(20-50 \mu \mathrm{m})$ and $35-70 \%$ with the clay-size fraction $(0-20 \mu \mathrm{m})$ (Feller and Beare, 1997). The fine-clay fraction contains less stable SOM than the coarser fine silt and coarse clay fractions. In contrast, some studies have shown that the stability of OM increase with decrease in the particle-size fraction (Christensen, 1992). The interaction between clay and SOC concentration is determined by the molecular structure of clay and requires a review of the different clay minerals that are normally found in tropical soils. A classification scheme for phyllosilicates related to clay materials..

\section{Transport of dissolved organic carbon into subsoil horizons}

The dissolved organic carbon (DOC) is defined as all carbon of plant, animal, fungi and/or bacteria origin that is dissolved in a given volume of water at a particular temperature and pressure. These dissolved organic carbon compounds are comprised of soluble carbohydrates, amino acids to more complex high-molecular weight molecules. The chemical structure of Dissolved organic carbon molecules can be recognizable and easily defined, such as fats, carbohydrates, and proteins. However, most have nonidentifiable structure and are lumped under the term humic or tannin substances. Recent studies indicate that the oceanic DOC reservoir may be comparable in size to the terrestrial $\mathrm{C}$ reservoir. 


\section{Formation of secondary carbonates}

Despite the dominant role that calcium carbonate plays in modifying the physical, chemical and biological properties and behaviour of plant nutrients in the soil, its role in $\mathrm{C}$ sequestration in calcareous soils is not widely documented (Lal, 2002). The role of SIC is important for sequestering $\mathrm{C}$, but the mechanisms involved are not well understood.

The rate of SIC sequestration as secondary carbonates is low ( 2 to $5 \mathrm{~kg} \mathrm{C} h a^{-1} \mathrm{yr}^{-1}$ ) and is accentuated by biogenic processes and leaching of carbonates into the groundwater (Nordt et al., 2001), especially in soils irrigated with water containing low carbonates.

The soil inorganic carbon occurs in carbonate minerals in two forms, i.e. calcium carbonate $\left(\mathrm{CaCO}_{3}\right)$ and dolomite $\left(\mathrm{MgCO}_{3}\right)$. In tropical highly weathered acid-soils the amount of soil inorganic carbon is not considerable because most of the carbonates present in the parent material have been dissolved. Fractions of soil organic carbon are given in table which is shown as under in table 1.

Total soil organic and inorganic carbon pools in world

Estimates of soil organic and inorganic carbon pools in world soils given by Eswaran et al., 1993 and studied that the inorganic carbon was found more in aridisols which is approximately 1044 tons per hactere, aridisols are soils which are found in arid and semi arid regions. While as organic carbon was found more in Histosols. Histosols are soils which contain organic carbon percentage more as compared to other soil orders. Table 2 below shows the content of organic carbon and inorganic carbon content in world soil given in tons per hector.
Carbon sequestration and storage, and the resilience of carbon stocks

Important climate-related functions of forest ecosystems are carbon sequestration and carbon storage, which create carbon stocks. The persistence and resilience of these carbon stocks as well as the continued ability of forests to absorb carbon dioxide from the atmosphere are significant factors in the role that forests can play in climate change mitigation (Díaz et al., 2009), particularly in a world characterised by rapid change. This section is built on a critical review of five existing reviews and syntheses on biodiversity and, carbon stocks and their resilience (Brodie et al., 2012; Midgley et al., 2010; Miles et al., 2010a; Parotta et al., 2012; Thompson et al., 2012), as well as additional related literature found through supplementary searches. As such, this section has not applied the same search and appraisal methodology as other sections of the review; however, the findings are presented in a similar way, using the same levels of confidence as applied throughout the review.

\section{Carbon sequestration and insect mass} outbreaks

In such cases, not only has tree species composition changed but also the character of the entire landscape, resulting in an increased deterioration of forests and their associated fauna and flora. This phenomenon is known to occur in managed forest systems as well as in their unmanaged counterparts. At the biogeochemical scale, forest insects also have the potential to greatly affect nutrient cycles in terms of quantity and quality, with substantial consequences for $\mathrm{C}$ and $\mathrm{N}$ storage capabilities in above and below-ground systems. During mass outbreaks (defoliation), insect-mediated organic matter fluxes from canopy to soil foster soil decomposition activity of microorganisms and subsequently 
elevates $\mathrm{CO}_{2}$ and $\mathrm{N}_{2} \mathrm{O}$ production significantly. In forest ecosystems, insect mass outbreaks following severe or repeated periods of drought might therefore serve as a trigger for converting carbon sinks turn into carbon sources due to limited $\mathrm{C}$ sequestration in woody material and enhanced soil-induced respiration. Due to an insect induced limited above and below ground $\mathrm{C}$ sequestration ability and an enhanced production of $\mathrm{CO}_{2}$ and $\mathrm{N}_{2} \mathrm{O}$ forest stands with an enhanced susceptibility to mass outbreaks are likely to occur with an increased global warming potential (GWP).

\section{Carbon credits and debits from land management}

The Kyoto Protocol currently provides incentives for two different types of land management activities that could reduce atmospheric $\mathrm{CO}_{2}$ concentrations, one explicitly and the other implicit in the details of the Protocol. Removal of $\mathrm{CO}_{2}$ from the atmosphere by sinks (carbon sequestration) is explicitly discussed in the Protocol. Implicitly, substitution of biomass energy for fossil-fuel energy or of biomass based materials for alternate, more energy-intensive materials can reduce a country's emissions of $\mathrm{CO}_{2}$. Whereas all combustion of fossil-fuels results in emissions of $\mathrm{CO}_{2}$ that would need to be counted under the Kyoto Protocol, the combustion of recently grown plant material is counted only if it results in a change in the standing stock of plant biomass. These two types of activities raises interesting, but different, challenges for conservation of biodiversity because the harvest of biomass fuels or biomass products has different landuse implications than does carbon sequestration.

\section{Soil carbon sequestration and tillage}

Both positive and negative effects of tillage on SOC stocks have been reported in the literature as reviewed in several recent studies summarized by Kätterer et al., (2013a). In several reviews, the importance of crop production response to tillage operations has been emphasized. According to a recent meta analysis, annual $\mathrm{C}$ inputs to soil were the only factor that could significantly explain differences in soil $\mathrm{C}$ stocks between tillage systems (Virto et al., 2012). Increases in SOC under no-till are likely to occur as long as $\mathrm{C}$ inputs are at least equal or greater than $85 \%$ of those in tilled systems (Ogle et al., 2012), in a review of European data, it was shown that yields under no-till were, on average, $8.5 \%$ lower than those under conventional tillage, albeit results varied between countries and soil types (Van de Putte et al., 2010). Under Scandinavian conditions, tillage effects on crop yields are small (Rasmussen, 1999).

\section{Soil carbon sequestration in conservation agriculture}

Conservation agricultural systems sequester carbon from the atmosphere into long-lived soil organic matter pools - while promoting a healthy environment and enhancing economically sustainable production conditions for farmers throughout the world. Soil organic carbon is fundamental to the development of soil quality and sustainable food production systems. Soil, soil organic carbon, and soil quality are the foundations of human inhabitation of our Earth. We must enhance the ability of soil to sustain our lives by improving soil organic carbon. Conservation agriculture systems have three guiding principles that can be globally applied: - Minimizing soil disturbance, consistent with sustainable production

- Maximizing soil surface cover by managing crops, pastures and crop residues

- Stimulating biological activity through crop rotations, cover crops and integrated nutrient and pest management. These three principles help to assure the positive balance between carbon inputs and carbon outputs. 
Table.1 Fractions of soil organic carbon

\begin{tabular}{|c|c|c|}
\hline SOC material & Composition & Pool category \\
\hline Surface plant residue & $\begin{array}{l}\text { Plant material residing on the } \\
\text { surface of the soil, including } \\
\text { leaf litter and crop/ pasture } \\
\text { material }\end{array}$ & $\begin{array}{l}\text { Fast (or labile) pool } \\
\text { Decomposition occurs at a } \\
\text { timescale of days to years }\end{array}$ \\
\hline Buried plant residue & $\begin{array}{l}\text { Plant material greater than } 2 \\
\text { mm in size residing within the } \\
\text { soil }\end{array}$ & $\begin{array}{l}\text { Fast (or labile) pool } \\
\text { Decomposition occurs at a } \\
\text { timescale of days to years }\end{array}$ \\
\hline $\begin{array}{l}\text { Particulate organic matter } \\
\text { (POC) }\end{array}$ & $\begin{array}{l}\text { Semi-decomposed organic } \\
\text { material smaller than } 2 \mathrm{~mm} \text { and } \\
\text { greater than } 50 \mu \mathrm{m} \text { in size }\end{array}$ & $\begin{array}{l}\text { Fast (or labile) pool } \\
\text { Decomposition occurs at a } \\
\text { timescale of days to year }\end{array}$ \\
\hline 'Humus' & $\begin{array}{l}\text { Well decomposed organic } \\
\text { material smaller than } 50 \mu \mathrm{m} \text { in } \\
\text { size that is associated with soil } \\
\text { particles }\end{array}$ & $\begin{array}{l}\text { Slow (or stable) pool } \\
\text { Decomposition occurs at a } \\
\text { timescale of years to decades }\end{array}$ \\
\hline Resistant organic carbon (ROC) & $\begin{array}{l}\text { Charcoal or charred materials } \\
\text { that results from the burning of } \\
\text { organic matter (resistant to } \\
\text { biological decomposition) }\end{array}$ & $\begin{array}{l}\text { Passive (or recalcitrant) pool } \\
\text { Decomposition occurs at a } \\
\text { timescale of decades to } \\
\text { thousands of years }\end{array}$ \\
\hline
\end{tabular}

Table.2 Content of organic carbon and inorganic carbon content in world soil

\begin{tabular}{|l|l|l|}
\hline \multirow{2}{*}{ Soils } & \multicolumn{2}{|l|}{ Carbon pool to 1-m depth } \\
\cline { 2 - 3 } & $\begin{array}{l}\text { Organic } \\
\text { (tons/hac) }\end{array}$ & $\begin{array}{l}\text { Inorganic } \\
\text { (tons/hac) }\end{array}$ \\
\hline Ultisols & 101 & 0 \\
\hline Andisols & 69 & 1 \\
\hline Aridisols & 110 & 1044 \\
\hline Oxisols & 150 & 0 \\
\hline Inceptisols & 267 & 258 \\
\hline Alfisols & 136 & 127 \\
\hline Mollisols & 72 & 139 \\
\hline Vertisols & 38 & 25 \\
\hline Spodosols & 98 & 0 \\
\hline Entisols & 106 & 117 \\
\hline Histosols & 390 & 0 \\
\hline Miscellaneous & 18 & 0 \\
\hline Total & 1555 & 1738 \\
\hline
\end{tabular}


Fig.1 General structure of soil aggregation

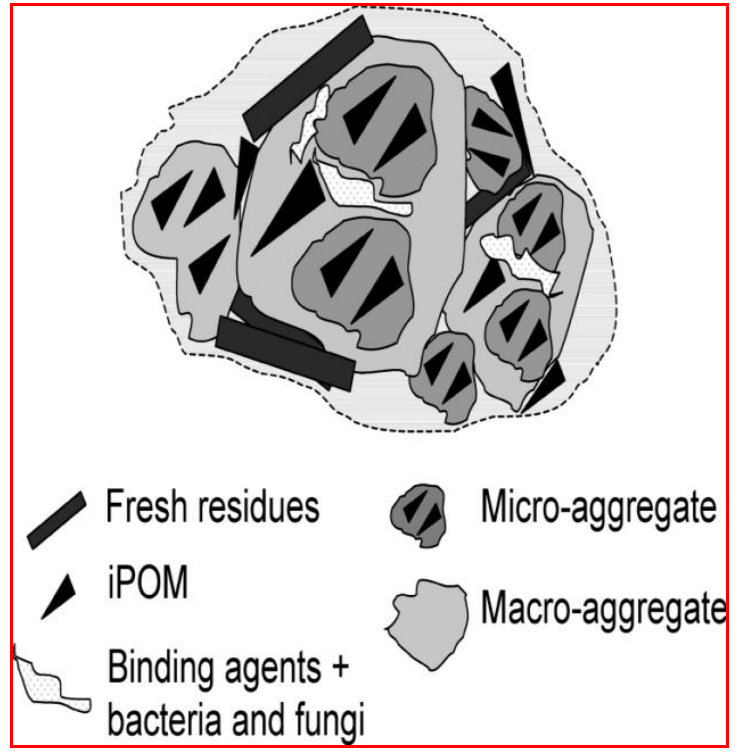

\section{Carbon sequestration in forest}

Land use change and forest management effects on biomass carbon stocks are relatively well known, but effects on soil $\mathrm{C}$ stocks are more scarcely reported and appear less consistent. Recent changes in agricultural policies and targeted afforestation programs have led to natural or planned afforestation of former grassland and cropland throughout Europe (Fuchs et al., 2013). Several recent field-scale and meta-analysis studies have highlighted that rates of SOC sequestration following afforestation depends on previous land use, e.g. rates of SOC sequestration are higher in afforested cropland than in afforested grassland (Poeplau et al., 2011). However, uncertainties are large, and little is known about temporal dynamics, the key processes and stability of sequestered SOC. A few recent studies have synthesized evidence regarding forest management effects on SOC (Lal, 2005; Jandl et al., 2007), but generalizable quantitative information is limited for specific management issues. Some of these are e.g. change in tree species and species diversity, rotation length, management intensity, continuous cover

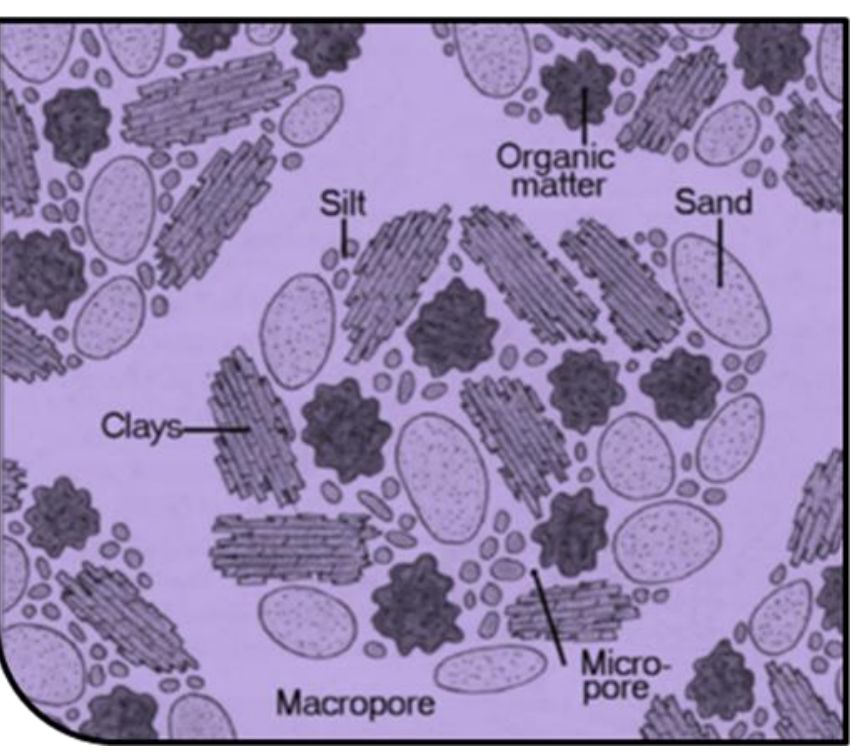

forestry, harvesting intensity and soil drainage. Current trends in forest management may support (reduced drainage) as well as compromise (e.g. whole-tree harvesting) SOC sequestration.

\section{Carbon sequestration in cropland}

The historic expansion of agricultural land has led to large soil organic carbon losses (Lal and Follett, 2009). The present net loss of C from tropical vegetation and soils caused by land use change is according to recent estimates $1.3 \pm 0.7 \mathrm{Pg} \mathrm{C} \quad \mathrm{yr}^{-1}$, which corresponds to approximately $17 \%$ of the $\mathrm{CO}_{2}$ emissions caused by fossil fuels and cement production (Pan et al., 2011). As soil SOC stocks are generally higher in grassland and forest ecosystems, land use conversion into cropland results in most cases in a net increase of $\mathrm{CO}_{2}$ emissions from soils (Poeplau et al., 2011). Cropland management has been proposed as a cost-effective option for soil carbon sequestration (Freibauer et al., 2004). Previous estimates of the sequestration potential in European soils (Freibauer et al., 2004) were very optimistic. However, biological $\mathrm{C}$ sequestration is limited and its 
finite and reversible effects with respect to climate mitigation have been documented (Paustian et al., 1998; Andrén and Kätterer, 2001). Moreover, options where local and short-term accumulation of soil $\mathrm{C}$ rather than long-term $\mathrm{C}$ sequestration have been accounted are the major reason for too optimistic estimates. We emphasize that the term 'carbon sequestration' should only be used for options leading to additional retention of $\mathrm{C}$ in soils (Powlson et al., 2008; Kätterer et al., 2013a) by a net removal of C from the atmosphere through photosynthesis resulting in soil organic matter pools with long turnover times. However, changes in management practices that reduce $\mathrm{CO}_{2}$ emissions from soils compared to the status quo will also contribute to mitigation even if this will not lead to a net $\mathrm{C}$ sequestration in soil.

\section{Carbon sequestration in wetlands}

Wetlands cover about $3 \%$ of the global land area, but contain $20-30 \%$ of the terrestrial stocks of soil organic carbon. It is highly important to protect these vulnerable stocks which are seriously threatened by drainage and climate change. In wetlands decomposition can be aerobic inside soils or at the sediment/water interface, but is anaerobic in deeper waterlogged zones or in the centre of particles under anaerobic condition electron acceptor other than $\mathrm{O}_{2}$ are used for decomposition of organic compounds. Anaerobic oxidation is energetically less efficient than aerobic oxidation in the sense that more substrate is needed to provide the same amount of energy. However, because the $\mathrm{C} / \mathrm{N}$ ratio of aerobic and anaerobic decomposers is similar, more $\mathrm{N}$ is mineralized under anaerobic than under aerobic conditions. Usually anaerobic conditions are associated with incomplete decomposition as in evidenced by poorly decomposed plant remains in peat. However,
Neue and Scharpenseel (1987) showed that decomposition of $14 \mathrm{c}$ labeled straw in the tropics was as rapid in flooded, anaerobic, soils as in aerobic soils. Peat may play an important role in the net $\mathrm{C}$ exchange between the terrestrial biosphere and the atmosphere since the amount of $\mathrm{C}$ stored on an areal basis may be up to ten times larger than in other terrestrial ecosystems (Schlesinger, 1991). In addition peat often plays a major role in the C.

\section{Carbon sequestration in grasslands}

Different management practices on grassland/rangeland, involving internal nutrient cycling on farms, have been shown to result in fast increases in soil carbon and lower energy use of non-renewable sources. Climate change can pose a threat to carbon stocks in grassland/rangeland as higher temperatures lead to acceleration of decomposition of organic carbon in litter and soil and decreased soil moisture, resulting in loss of carbon and ecosystem degradation. Grasslands and savannas cover $20 \%$ of the earth's land surface (Lieth, 1975) and store $30 \%$ of global soil organic carbon Field et al, 1998. Grassland ecosystems managed for livestock production represent the largest land-use footprint globally, covering more than one-quarter of the world's land surface (Asner et al., 2004). Global estimates of the relative amounts of carbon in different vegetation types suggest that grasslands probably contribute $>10 \%$ of the total biosphere store (Nosberger et al., 2000). Plant diversity greatly influences carbon accumulation rates in grasslands. The presence of species with differing functional traits increases soil carbon and nitrogen accumulation (Fornara and Tilman, 2008). Carbon from plants enters the SOC pool in the form of either aboveground litter or root material. Greater carbon accumulation is associated with greater root biomass (i.e., 
greater carbon and nitrogen inputs in the soil) resulting from positive interactions among legumes and $\mathrm{C} 4$ grasses and the greater soil depths through which their roots are located at higher diversity (Fornara and Tilman, 2008) turnover in aquatic ecosystems.

\section{Key research issues need to resolve}

Developing low cost methods of accounting for soil carbon;

Quantifying net carbon sequestration under different management practices for different soil types, climates and agricultural systems;

Supporting existing long term cropping rotation trial sites and the establishment of new ones where appropriate; and

Soil carbon models need to be updated to account for locally relevant agricultural management practices.

In conclusion soil carbon sequestration and preservation of present stocks reduces net global greenhouse gas emission and can contribute significantly to both Nordic and international goals of limiting serious climate change. In order to achieve this, sustainable use of soil resources, better soil and water management practices, and restoration of degraded soils is needed. Protection and restoration of soil organic carbon are also key solutions to many of the most pressing global challenges facing mankind today. Highlighting the importance of the soil and the multiple benefits of soil organic carbon sequestration has never been more needed than now.

\section{References}

Andrén, O. and T. Kätterer. 2001. "Basic Principles for Soil Carbon Sequestration and Calculating Dynamic Country-level Balances Including Future Scenarios" in Lal, R., J.M. Kimble, R.F. Follett and B.A. Stewart. eds.): Assessment Methods for Soil Carbon, Lewis Publishers. pp. 495-511.

Asner, G.P., Elmore, A.J., Olander, L.P., Martin, R.E., Harris, A.T. 2004. Grazing systems, ecosystem responses, and global change. Annual Review of Environ. Res., 29: 261- 299.

Bonde, T.A., Christensen, B.T., and Cerri, C.C. 1992. Dynamics of soil organic matter as reflected by natural $13 \mathrm{C}$ abundance in particle size fractions of forested and cultivated oxisols. Soil Biol. Biochem., 24: 275-277.

Brodie, J., Post, E. and Laurance, W.F. 2012. Climate change and tropical biodiversity: a new focus. Trends in Ecol. Evol., 27(3):145-150.

Díaz, S., Hector, A. and Wardle, D.A. 2009. Biodiversity in forest carbon sequestration initiatives: not just a side benefit. Curr. Opinion in Environ. Sustainability, 1(1): 55-60.

Eswaran, H., van der Berg, E., and Reich, P. 1993. Organic carbon in soils of the world. Soil Sci. Soc. Am. J., 57: 192-194.

Feller, C., and Beare, M.H. 1997. Physical control of soil organic matter dynamics in the tropics. Geoderma, 79: 69-116.

Feller, C., François, C., Villemin, G., Portal, J.M., Toutain, F. and Morel, J.L. 1991. Nature des matières organiques associées aux fractions argileuses d'un sol ferrallitique. C. R. Acd. Sci. Paris, Sér(2) 312: 1491-1497.

Field, C., Behrenfeld, M., Randerson, J., Falkowski, P. 1998. Primary production of the biosphere: integrating terrestrial and oceanic components. Sci., 281: 237240.

Fornara, D.A., Tilman, D. 2008. Plant functional composition influences rates of soil carbon, J. Ecol., 96: 314-322.

Freibauer, A., M.D.A. Rounsevell, P. Smith and J. Verhagen. 2004. Carbon sequestration in the agricultural soils of Europe, Geoderma, 122: 1-23.

Fuchs, R., Herold, M., Verburg, P.H., and Clevers, J.G.P.W. 2013. A highresolution and harmonized model 
approach for reconstructing and analysing historic land changes in Europe. Biogeosci., 10: 1543- 1559.

Gijsman, A.J. 1996. Soil aggregate stability and soil organic matter fractions under agropastoral systems established in native savanna. Aust. J. Soil Res., 34: 891-907.

Gijsman, A.J. and Thomas, R.J. 1995. Aggregate size distribution and stability of an Oxisol under legume-based and pure grass pasture in the Eastern Colombian savannas. Aust. J. Soil Res., 33: $153-165$.

Guggenberger, G., Zech, W. and Thomas, R.J. 1995. Lignin and carbohydrate alteration in particle-size separates of an Oxisol under tropical pastures following native savanna. Soil Biol. Biochem., 27: 16291638 .

Jandl, R., Lindner, M., Vesterdal, L., Bauwens, B., Baritz, R., Hagedorn, F. et al. 2007. How strongly can forest management influence soil carbon sequestration? Geoderma, 137: 253-268.

Kätterer, T., M.A. Bolinder, K. Berglund and H. Kirchmann. 2013a. Strategies for carbon sequestration in agricultural soils in northern Europe, Acta Agriculturae Scandinavica Section A - Animal Science. Published online: http://dx.doi.org/10.1080/09064702.2013. 779316

Laird, D.A. 2001. Nature of clay humic complexes in an agricultural soil. II. Scanning electron microscopy analysis. Soil Sci. Soc. Am. J., 65: 1419- 1425.

Lal, R. 2002. The potential of soils of the tropics to sequester carbon and mitigate the greenhouse effect. Adv. Agron., 76: 130.

Lal, R. 2004. Soil carbon sequestration impacts on global change and food security. Sci., 304: 1623- 1627.

Lal, R. 2005. Forest soils and carbon sequestration. Forest Ecol. Management, 220: 242-258.

Lal, R. and R.F. Follett. 2009. Soil Carbon Sequestration and the Greenhouse Effect. SSSA Special Publication 57, second edition. Madison, WI: Soil Science Society of America.

Lam, S.K., D. Chen, A.R. Mosier, R. Roush. 2013. The potential for carbon sequestration in Australian agricultural soils is technically and economically limited. Scientific Reports, 3: 2179.

Lieth H. 1975 Modeling the primary productivity of the world. In: Lieth $\mathrm{H}$, Whittaker RH. Eds. Primary Productivity of the Biosphere. Springer-Verlag, New York. 237-263.

Midgely, G.F., Bond, W.J., Kapos, V., Ravilious, C., Scharlemann, J.P., and Woodward, F.I. 2010. Terrestrial carbon stocks and biodiversity: key knowledge gaps and some policy implications. Curr. Opinion in Environ. Sustainability, 2: 17.

Miles, L., Dunning, E., Doswald, N., and Osti, M. 2010a. A safer bet for REDD+: Review of the evidence on the relationship between biodiversity and the resilience of forest carbon stocks. Multiple Benefits Serie, 10.

Neue, H.U. and Scharpenseel, H.W. 1987. Decomposition pattern of 14C -labeled rice straw in aerobic and submerged rice soils of the Philippines. The Sci. Total Environ., 62: 431-4.

Nordt, L.C., Wilding, L.P., and Drees, L.R. 2001. Pedogenic carbonate transformations in leaching soil systems: implications for the global carbon cycle. In: Lal, R., Kimble, J. M., Eswaran, H., Stewart, B. A. Eds.), Global Climate Change and Pedogenic Carbonates, pp. 43-63. CRC/Lewis, Boca Raton, FL.

Nosberger, J., Blum, H., Fuhrer, J. 2000. Crop ecosystem responses to climatic change: Productive grasslands. In: Hodges HF. Ed.), Climate Change and Global Crop Productivity, CAB International, Wallingford, UK. 271- 291.

Ogle, S.M., A. Swan and K. Paustian. 2012. No-till management impacts on crop productivity, carbon input and soil carbon sequestration, Agri. Ecosystems and Environ., 149: 37-49. 
Pan, Y., R.A. Birdsey, J. Fang, R. Houghton, P.E. Kauppi, W.A. Kurz, O.L. Phillips, A. Shvidenko, S.L. Lewis, J.G. Canadell, P. Ciais, R.B. Jackson, S.W. Pacala, A.D. McGuire, S. Piao, A. Rautiainen, S. Sitch and D. Hayes. 2011. A large and persistent carbon sink in the world's forests, Sci., 333: 988-993.

Parrotta, E.J.A., Wildburger, C. and Mansourian, S. 2012. Understanding Relationships between Biodiversity, Carbon, Forests and People: The Key to Achieving REDD+ Objectives, International Union of Forest Research Organizations. IUFRO): Vienna, Austria.

Paustian, K., C.V. Cole, D. Sauerbeck and N. Sampson. 1998. $\mathrm{CO}_{2}$ mitigation by agriculture: an overview, Climatic Change, 40: 135-162.

Poeplau, C., Don, A., Vesterdal, L., Leifeld, J., van Wesemael, B., Schumacher, J. et al. 2011. Temporal dynamics of soil organic carbon after land use change in the temperate zone - carbon response functions as a model approach. Global Change Biol., 17: 2415-2427.

Powlson, D.S., A.B. Riche, K. Coleman, M.J. Glendining and A.P. Whitmore. 2008. Carbon sequestration in European soils through straw incorporation: limitations and alternatives, Waste Management, 28: 741- 746.

Rasmussen, K.J. 1999. Impact of ploughless soil tillage on yield and soil quality: A Scandinavia review, Soil Tillage Res., 53: 3-14.

Schlesinger, W.H. 1991. Biogeochemistry: An
Analysis of Global Change. Academic Press, San Diego. 443 p. Fifth printing, 1995.

Talbot, J.D. 2010. Carbon and biodiversity relationships in tropical forests. Multiple Benefits Series 4, prepared on behalf of the UN-REDD Programme. UNEP World Conservation Monitoring Centre: Cambridge, UK.

Thompson, I.D., Ferreira, J., Gardner, T., Guariguata, M., Koh, L.P., Okabe, K., Pan, Y., Schmitt, and C. B., Tylianakis, J. 2012. Forest biodiversity, carbon and other ecosystem services: relationships and impacts of deforestation and forest degradation. In Parotta et al. Eds), Understanding Relationships between Biodiversity, Carbon, Forests and People: The Key to Achieving REDD+ Objectives, A Global Assessment Report. Prepared by the Global Forest Expert Panel on Biodiversity, Forest Management, and REDD+. IUFRO World Series Volume 31: Vienna, Austria, pp. 21-52.

Van de Putte, A., G. Govers, J. Diels, K. Gillijns and M. Demuzere. 2010. Assessing the effect of soil tillage on crop growth: A meta-regression analysis on European crop yields under conservation agriculture, J. Agron., 33: 231-241.

Virto, I., P. Barré, A. Burlot and C. Chenu. 2012. Carbon input differences as the main factor explaining the variability in soil organic $\mathrm{C}$ storage in no-tilled compared to inversion tilled agrosystems, Biogeochem., 108: 17-26.

\section{How to cite this article:}

Mehraj ud din Khanday, J.A. Wani, D. Ram and Rukhsana Jan. 2017. Quantifying the Stock of Soil Carbon Sequestration in Different Land Uses: An Overview. Int.J.Curr.Microbiol.App.Sci. 6(4): 382-392. doi: https://doi.org/10.20546/ijcmas.2017.604.050 